\title{
СТРАТЕГІЧНЕ УПРАВЛІННЯ ПЕРСОНАЛОМ ЯК ЧИННИК ПІДВИЩЕННЯ КОНКУРЕНТОСПРОМОЖНОСТІ ПІДПРИЄМСТВА
}

\author{
STRATEGIC PERSONNEL MANAGEMENT AS A FACTOR \\ OF IMPROVING COMPETITIVENESS OF AN ENTERPRISE
}

\author{
Овчарук О.М. \\ кандидат економічних наук, доцент кафредри менеджменту, \\ Полтавська державна аграрна академія \\ ORCID: https://orcid.org/0000-0002-3043-9271
}

\author{
Ovcharuk Olena \\ Poltava State Agrarian Academy
}

\begin{abstract}
Актуальність теми дослідження зумовлена необхідністю здійснення комплексних досліджень стратегічного управління персоналом підприємства з метою забезпечення його конкурентоспроможності. Автором зазначено, що стратегія управління персоналом має бути всеосяжною в сенсі націлювання кадрового складу організації на досягнення цілей ї̈ довготривалого розвитку. У цьому разі планування управління персоналом стає складовою частиною бізнес-планування, а розроблення стратегії управління персоналом розглядається як пріоритетний бізнес-процес. Розглянуто основні причини нестабільності кадрового складу підприємства та шляхи розв'язання проблем стратегічного управління персоналом суб'єкта дослідження. Запропоновані заходи передбачають цілеспрямовану побудову оптимальної системи управління персоналом та кадрової структури за кількісними та якісними характеристиками, що дає можливість забезпечити найбільш ефективне використання підприємством кадрових ресурсів.
\end{abstract}

Ключові слова: ефрективність, конкурентоспроможність, система управління, стратегічне управління, менеджмент, персонал підприємства, управління.

Актуальность темы исследования обусловлена необходимостью осуществления комплексных исследований стратегического управления персоналом с челью обеспечения его конкурентоспособности. Автором отмечено, что стратегия управления персоналом должна быть всеобъемлющей в смысле нацеливания кадрового состава организации на достижение целей ее долговременного развития. В этом случае планирование управления персоналом становится составной частью бизнес-планирования, а разработка стратегии управления персоналом рассматривается в качестве приоритетного бизнес-процесса. В статье рассмотрены основные причины нестабильности кадрового состава предприятия и пути решения проблем стратегического управления персоналом субъекта исследования. Предложенные меры предусматривают целенаправленное построение оптимальной системы управления персоналом и кадровой структуры по количественным и качественным характеристикам, что позволяет обеспечить наиболее эфффективное использование предприятием кадровых ресурсов.

Ключевые слова: эфффективность, конкурентоспособность, система управления, стратегическое управление, менеджмент, персонал предприятия, управление.

The relevance of the research topic is conditioned by the need for a comprehensive study of strategic personnel management of an enterprise in order to ensure its competitiveness. The author states that the personnel management strategy should be all-embracing in the sense of targeting the staff of an organization to achieve the goals of its long-term development. In this case, personnel management planning becomes an integral part of business planning, and the development of personnel management strategy is considered as a priority business process. In the author's opinion, to attract and consolidate personnel, the management of an enterprise should create and maintain the following conditions: a proper system of remuneration, engagement and favourable staff morale; continuous advanced training of employees; opportunities for career and scientific growth. It is noted that first, it will be advisable to implement a preventive staff policy, which provides not only control over the negative aspects of the work with personnel, causes and situation of the crisis development, the elaboration of measures to localize the crisis, but also the formation of enterprise development programs containing short-term and medium-term forecasts in recruitment needs, formulated tasks for staff development. The given research of personnel management strategy suggests that the first step in implementing measures to improve the effectiveness of strategic management is the development of a personnel management concept - a comprehensive understanding of the essence, goals, objectives, principles 
and methods of personnel management under specific conditions of production and management business processes. However, it is found that, on the one hand, there are financial restrictions that are conditioned by the limit of funds for staff maintenance and largely affect such decision-making (raise in salary of all employees or certain categories, staff expansion while maintaining the existing level of remuneration, purchase of office equipment, etc.). On the other hand, social restrictions are the result of general trends in the labour market in the country and the regions, the social policy of the state, the requirements of trade unions to employers. The article considers the main causes of instability of the staff of an enterprise and ways to solve the problems of strategic personnel management of the research subject. The proposed measures provide for the purposeful construction of an optimal system of personnel management and staffing structure according to quantitative and qualitative characteristics, which makes it possible to ensure the most effective use of human resources by an enterprise.

Key words: effectiveness, competitiveness, management system, strategic management, management, personnel of an enterprise.

Постановка проблеми. Поява сучасних моделей організації бізнесу та їх упровадження у вітчизняних і зарубіжних компаніях вимагають переосмислення наукових поглядів як на організаційну стратегію, так і на стратегію управління персоналом, зумовлюють необхідність формування нових підходів до розроблення стратегії та створення нових концепцій стратегічного управління персоналом в умовах розвитку прогресивних форм організації і процесного управління діяльністю компаній.

Нині кадрова робота на багатьох вітчизняних підприємствах фрактично будується без урахування сучасних тенденцій у розвитку світового бізнесу. Це породжує їх відставання в конкурентоспроможності, яке виражається в якості рішень і дій, продуктивності праці, інновації і т. д. Розуміння значення людського чинника визначає його роль і статус у сучасній організації, тобто реальну і перспективну значущість як усієї системи управління персоналом, так і її стратегічного складника.

Стратегія управління персоналом має бути всеосяжною в сенсі націлювання кадрового складу організації на досягнення цілей ії довготривалого розвитку. У цьому разі планування управління персоналом стає складовою частиною бізнес-планування, а розроблення стратегії управління персоналом розглядається як пріоритетний бізнес-процес.

Актуальність теми дослідження зумовлена необхідністю здійснення комплексних досліджень стратегічного управління персоналом підприємства з метою забезпечення його конкурентоспроможності.

Аналіз останніх досліджень і публікацій. Слід зазначити, що в літературі досить широко висвітлено різні аспекти стратегічного управління людським ресурсами. Це підтверджується роботами таких науковців, як І. Ансофрф, М. Армстронг, Л. Балабанова, Л. Бившева, Ю. Вакуленко, О. Галич, Г. Емерсон, А. Кибанов, Т. Крутько, І. Терещенко та ін. Підкреслюється, що стратегічне управління і концепція управління людськими ресурсами можуть підвищити конкурентоздатність підприємства, створити його додаткові цінності, сфрормувати ефективне управління підприємством. Формування стра- тегічних напрямів і поліпшення нематеріальних активів визначаються пріоритетами у фрормуванні та розробленні стратегій.

А. Кібанов, І. Дуракова розглядають стратегію управління персоналом як розроблений керівництвом організації пріоритетний, якісно визначений напрям дій, які необхідні для досягнення довгострокових цілей зі створення високопрофресійного, відповідального і згуртованого колективу й ураховують стратегічні завдання організації та її ресурсні можливості [9, с. 115].

Л. Балабанова, О. Сардак стверджують, що ефективне управління персоналом здійснюється на основі певних принципів:

1) цілеспрямованості - будь-який процес управління зорієнтований на досягнення конкретних бізнес-цілей організації. Відсутність чітко ссрормульованих цілей позбавляє роботу з персоналом спрямованості і значно знижує ії ефективність;

2) системності - усі дії стосовно персоналу повинні мати концептуальну єдність. Програми, процедури, практичні інструменти управління персоналом, які використовуються в різних сорерах (або на різних рівнях) управління персоналом, повинні становити єдину взаємопов'язану систему і не суперечити один одному;

3) науковості - суб'єкти управління повинні використовувати науково обґрунтовані методи в процесі управління персоналом [3].

Однак унаслідок складності й багатоаспектності цієї проблеми в сучасних умовах існують питання, які мало досліджені. Наприклад, питання організації персоналу і ролі кадрових служб залишаються методично не розробленими й висвітлені лише на рівні загальних рекомендацій. Таким чином, сьогодні необхідні теоретично обґрунтовані підходи до створення методики розроблення стратегії управління персоналом компанії.

Постановка завдання. Метою дослідження $€$ розроблення теоретичних положень і практичних рекомендацій щодо ефрективного стратегічного управління персоналом.

Виклад основного матеріалу дослідження. Стратегічне управління персоналом у рамках нового підходу до управління дає величезні переваги організаціям, срункціонуючим у різних 
сорерах життєдіяльності сучасного суспільства. Ці переваги полягають у раціональному використанні обмежених ресурсів і, головним чином, персоналу. Окрім того, стратегічний менеджмент надає відчуття впевненості персоналу організацій і їх менеджерам, сприяє послідовному розробленню та реалізації управлінських рішень, орієнтує на сталий розвиток в умовах ринку [5].

Вибір оптимального варіанту стратегії розвитку визначає суть організаційно-економічного механізму стратегічного управління персоналом у вигляді певної технології відбору, стимулювання і розвитку компетенцій працівників з урахуванням конкретних фрінансових, матеріальних і соціальних обмежень. Кадрова політка підприємства повинна спрямовуватися на залучення персоналу високої кваліфікації з творчими і підприємницькими здібностями [1, с. 87].

На нашу думку, для залучення і закріплення персоналу керівництво підприємства має створювати і підтримувати такі умови: належну систему оплати праці, мотивації і сприятливий морально-психологічний клімат; постійне підвищення кваліфрікації працівників; можливості службового і наукового зростання.

Уважаємо, що спочатку буде доцільною реалізація превентивної кадрової політики, яка передбачає не тільки контроль над негативними аспектами роботи з персоналом, причинами і ситуацією розвитку кризи, розробленням заходів щодо локалізації кризи, а й формування програм розвитку підприємства, що міститимуть короткостроковий і середньостроковий прогнози потреби в кадрах, сорормульовані завдання щодо розвитку персоналу.

Система управління персоналом має володіти не тільки засобами діагностики персоналу, а й прогнозування кадрової ситуації на середньостроковий період. Також система управління персоналом повинна охоплювати всі сорери кадрової діяльності підприємства на основі взаємозв'язаної політики і стратегії роботи 3 персоналом (рис. 1).

Розроблення стратегії управління персоналом підприємства повинно проводитися поетапно: визначення мети, критеріїв і показників ефрективності, фрінансових, матеріальних, соціальних обмежень, організаційної структури системи управління персоналом, її взаємозв'язків із зовнішнім середовищем [10] (рис. 2).

Здійснене дослідження стратегії управління персоналом дає можливість стверджувати, що першим етапом у реалізації заходів щодо підвищення есрективності стратегічного управління $€$ розроблення концепції управління персоналом - комплексного розуміння суті, цілей, завдань, принципів і методів управління персоналом у конкретних умовах здійснення виробничих і управлінських бізнес-процесів [7; 8].

Але встановлено, що, з одного боку, існують фрінансові обмеження, які зумовлені лімітом коштів на утримання персоналу і багато в чому впливають на ухвалення таких рішень (підвищення заробітної плати всіх працівників або окремих категорій, розширення штату співробітників за збереження існуючого рівня оплати праці, покупка засобів оргтехніки і т. д.). 3 іншого боку, соціальні обмеження $є$ результатом загальних тенденцій розвитку ринку праці в країні й у регіонах, соціальної політики держави, вимог профспілок до працедавців.

На основі проведеного дослідження системи управління персоналом приватного підприємства було виявлено, що в роботі суб'єкта дослідження є значні недоліки. Серед основних причин нестабільності кадрового складу підприємства можна виділити такі:

- неконкурентоспроможний рівень оплати праці;

- висока плинність кадрів;

- через низьку заробітну плату неможливість найняти висококваліфікованих спеціалістів.

Функціональна кадрова стратегія, елементи якої присутні у загальній стратегії управління персоналом суб'єкта дослідження, повинна, на нашу думку, бути спрямованою на залучення і закріплення кадрів, стабілізацію персоналу. На перший план виступають проблеми внутрішнього переміщення кадрів та їх перенавчання, посилення соціальних гарантій (табл. 1).

Однією з проблем, виявлених під час проведення аналізу, є недоліки в процесах пошуку,

\begin{tabular}{|c|c|c|c|}
\hline $\begin{array}{c}\text { Кадрове } \\
\text { планування }\end{array}$ & $\begin{array}{c}\text { Управління } \\
\text { персоналом }\end{array}$ & $\begin{array}{c}\text { Поточна } \\
\text { кадрова робота }\end{array}$ & $\begin{array}{l}\text { Мотивація } \\
\text { персоналу }\end{array}$ \\
\hline 4 & 4 & 4 & 4 \\
\hline \multicolumn{4}{|c|}{ Інструменти реалізації стратегії управління персоналом } \\
\hline$\downarrow$ & $\downarrow$ & $\downarrow$ & 1 \\
\hline $\begin{array}{c}\text { Заходи щодо } \\
\text { вирішення } \\
\text { соціальних }\end{array}$ & $\begin{array}{c}\text { Заходи щодо } \\
\text { навчання } \\
\text { персоналу }\end{array}$ & $\begin{array}{c}\text { Заходи щодо } \\
\text { оцінки } \\
\text { персоналу }\end{array}$ & $\begin{array}{c}\text { Заходи що } \\
\text { планування } \\
\text { управління кар'єрою }\end{array}$ \\
\hline
\end{tabular}

Рис. 1. Інструменти реалізації стратегії управління персоналом Джерело: систематизовано автором за [2; 4; 6] 


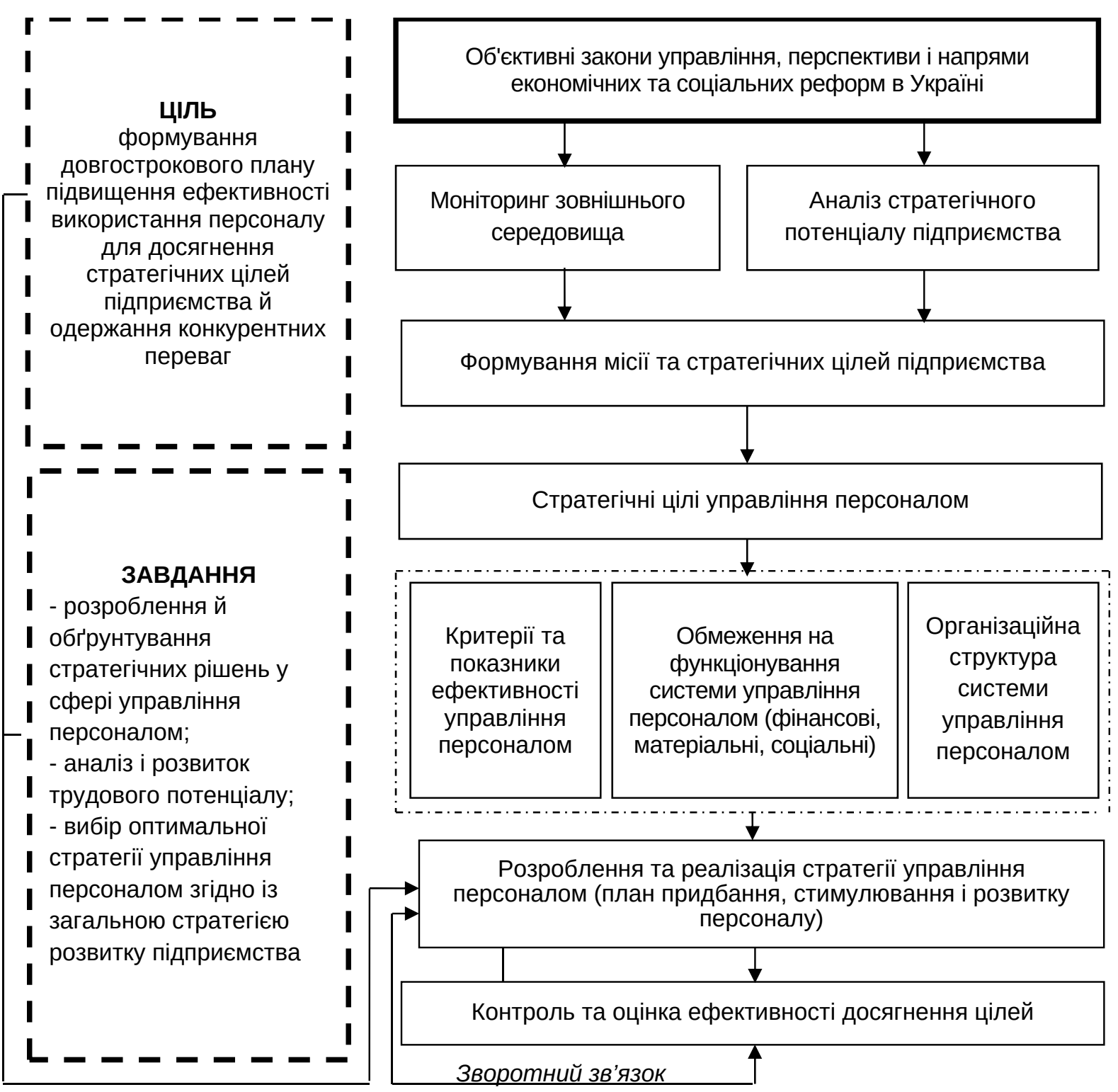

Рис. 2. Формування стратегії управління персоналом підприємства

Джерело: складено автором

добору і найму нових спеціалістів. Своєю чергою, це призводить до інших кадрових проблем, що виникають у роботі приватного підприємства. Через неефективний процес добору нових працівників виникла така проблема, як часта зміна керівника, що, своєю чергою, негативно впливає на загальні результати роботи всіх працівників підприємства.

Нами розглянуто послідовність та основні етапи добору працівників, яких повинна дотримуватися служба управління персоналом суб'єкта дослідження (рис. 3).

На досліджуваному підприємстві питання щодо добору нових працівників вирішують генеральний директор, лінійні керівники та менеджер із персоналу, що працює за контрактом, тобто ця вакансія не є штатною. Право на ухвалення остаточного рішення на заповнення вакансії певним кандидатом залишає за собою генеральний директор.

Для того щоб поліпшити процес пошуку нових спеціалістів, уважаємо, варто застосовувати всі можливі джерела пошуку кандидатів, як внутрішні (всередині підприємства), так і зовнішні (за його межами). Особливо слід звернути увагу на такі способи пошуку кандидатів:

1. Кадрові агентства. За нашим переконанням, співпраця з кадровими агентствами може виявитися більш доцільною, ніж постійний менеджер із персоналу, що працює на умовах аутсорсингу. Такі компанії самостійно ведуть пошук кандидатів за встановленими замовником вимогами.

2. Біржі праці, центри зайнятості. Цей вид пошуку персоналу сьогодні в Полтавському районі не є популярним. Однак варто пам'ятати, 
Взаємозв'язок пропонованої кадрової стратегії з корпоративною і конкурентною стратегією суб'єкта дослідження (складено автором)

\begin{tabular}{|c|c|c|}
\hline Стратегії & $\begin{array}{c}\text { Стратегічні цілі } \\
\text { управління персоналом }\end{array}$ & $\begin{array}{c}\text { Стратегічні напрями діяльності } \\
\text { щодо управління персоналом }\end{array}$ \\
\hline $\begin{array}{l}\text { Корпоративна } \\
\text { стратегія } \\
\text { (стратегія } \\
\text { обмеженого } \\
\text { зростання) }\end{array}$ & $\begin{array}{l}\text { Підтримка } \\
\text { конкурентоспроможності } \\
\text { персоналу }\end{array}$ & $\begin{array}{l}\text { Підвищення кваліфікації персоналу } \\
\text { Переміщення персоналу } \\
\text { Удосконалення системи розвитку персоналу }\end{array}$ \\
\hline $\begin{array}{l}\text { Конкурентні } \\
\text { стратегії } \\
\text { (стратегія } \\
\text { фокусування) }\end{array}$ & $\begin{array}{l}\text { Підвищення } \\
\text { конкурентоспроможності } \\
\text { персоналу } \\
\text { Збільшення витрат на персонал }\end{array}$ & $\begin{array}{l}\text { Підвищення кваліфрікації персоналу } \\
\text { Удосконалення системи розвитку персоналу } \\
\text { Залучення висококваліфрікованого персоналу вузької } \\
\text { спеціалізації } \\
\text { Удосконалення системи мотивації персоналу } \\
\text { Оптимізація організаційної побудови системи } \\
\text { управління персоналом }\end{array}$ \\
\hline
\end{tabular}

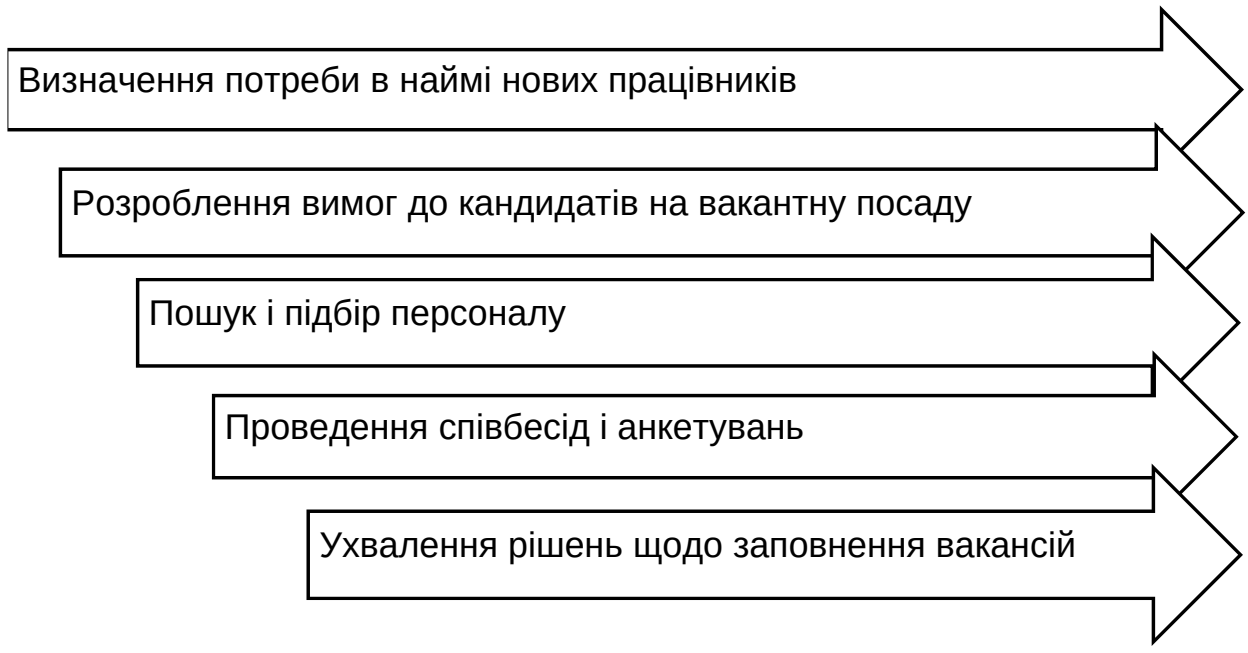

Рис. 3. Етапи пошуку та підбору нових працівників

Джерело: складено автором

що в такому разі підприємство не витрачає кошти на пошук і підбір персоналу. Кандидати відповідних спеціальностей направляються на підприємство, що мають потребу в таких трудових ресурсах.

Але не можна не зважати на те, що недолік цього методу полягає в обмеженій кількості потенційних працівників, оскільки відомо, що далеко не всі безробітні звертаються до служб і центрів зайнятості.

3. Рекомендації. Найстаріший і водночас досить ефективний спосіб пошуку потрібних спеціалістів. За статистикою підприємства, чисельність працівників в яких не перевищує 50 осіб, можуть заповнювати вакантні посади на 40\% через рекомендації та знайомства співробітників компанії. У цьому разі менеджеру 3 персоналу варто ретельніше перевіряти просресійні здібності потенційного працівника.

На нашу думку, підвищення ефективності системи управління персоналом підприємства можна забезпечити такими напрямами:
1. Удосконалення структури управління шляхом максимального її спрощення; децентралізація більшості функцій, визначення повноважень керівництва з урахуванням кваліфрікацій та особистих якостей.

2. Автоматизація та організація робочих місць. Уважаємо, що створення умов для високоефективної праці вимагає відповідної організації та обладнання робочих місць працівників, їх планування, забезпечення оптимальних умов праці.

3. Вироблення стратегії розвитку підприємства на основі аналізу її сильних і слабких сторін, розроблення фрілософіії і політики, що охоплює деякі зі сорер фрункціонування підприємства.

4. Розроблення інформаційної системи підприємства, що має забезпечувати ефективний комунікаційний зв'язок між співробітниками і підрозділами.

5. Розроблення системи прийняття рішень, правил і процедур управління, системи стимулювання. 
6. Розроблення системи підбору, навчання, оцінки і переміщення керівних кадрів, планування кар'єри керівників, застосування стилю керівництва, адекватного внутрішнім і зовнішнім чинникам, що впливають на підприємство.

7. Перехід від системи планування за принципом «зверху вниз» до «зустрічного», або змішаного, планування, за якого цільові завдання спускаються «зверху вниз», а способи їх вирішення фрормуються за принципом «знизу нагору». Широке запровадження ініціативних форм координації діяльності усіх суб'єктів, причетних до управління персоналом підприємства.

8. Матеріальне стимулювання персоналу; здійснення моніторингу заробітної плати й інших заохочувальних чинників. Збільшення фонду основної і додаткової заробітної плати. Це дасть змогу оцінювати сучасний стан проблеми, виявляти причини її виникнення, обґрунтовувати в статиці та динаміці шляхи адаптації системи матеріального стимулювання. Запровадження багаторівневої ступенево-безперервної системи соціально-статусних винагород, що складається 3 окремих елементів морального стимулювання, пов'язаних між собою. Запровадження нових прогресивних фрорм нематеріального стимулювання працівників розумової праці: підтримання атмосфери творчості, змагальності ідей, розробок; залучення працівників до процесу розроблення та прийняття управлінських рішень; створення творчих робочих груп працівників; широке використання системи позитивних стимулів і обережний підхід до застосування «негативних стимулів» (погроз, дисциплінарних санкцій тощо).

9. Надання соціального захисту та гарантій. Соціально-економічні заходи соціального захисту, крім матеріального забезпечення та обслуговування, мають передбачати компенсаційні виплати, відшкодування, поновлення прав та інші соціальні гарантії, які можуть визначатися нормами не тільки права соціального забезпечення, а й інших галузей права: трудового, цивільного, адміністративного, фрінансового та ін.

10. Робота зі створення культури на підприємстві, вироблення спільних цінностей, визнаних і схвалюваних співробітниками.

За нашим переконанням, ці заходи повинні вплинути на показник плинності кадрів, тобто зменшити кількість вивільнених працівників, скоротити час на виконання основних процесів та підвищити ефективність роботи працівників.

Висновки. Запропоновані заходи 3 визначення і реалізації стратегії управління персоналом підприємства передбачають цілеспрямовану побудову оптимальної системи управління персоналом та кадрової структури за кількісними та якісними характеристиками, що дає можливість забезпечити найбільш еорективне використання підприємством кадрових ресурсів.

Стратегія управління персоналом досліджуваного приватного підприємства повинна бути спрямована на вирішення важливих стратегічних завдань:

- створювати конкурентні переваги підприємства шляхом підвищення рівня відповідальності її працівників, використовуючи для цього засоби управління організаційною культурою;

- нарощувати конкурентні переваги підприємства шляхом удосконалення його потенціалу, всіма способами сприяючи зростанню його профресійної комплектації.

\section{БІБЛІОГРАФІЧНИЙ СПИСОК:}

1. Ансоффф И. Стратегическое управление. Москва : Экономика, 1989. 303 с.

2. Армстронг М. Стратегическое управление человеческими ресурсами. Москва : ИНФРА-М, 2002.328 с.

3. Балабанова Л.В., Сардак O.В. Управління персоналом. URL: http://www.twirpx.com/file/544700/ (дата звернення: 21.01.2021).

4. Стратегічне управління персоналом як фрактор зростання конкурентоспроможності промислового підприємства / Л.О. Бившева та ін. Економічний вісник Донбасу. 2020. № 1(59). C. 137-144. URL: http://dspace.nbuv.gov.ua/bitstream/handle/123456789/170211/20-Byvsheva.pdf?sequence=1 (дата звернення: 15.02.2021).

5. Стратегічне управління персоналом як фрактор зростання конкурентоспроможності підприємства / O.А. Галич та ін. Агросвіm. 2019. № 6. С. 27-32. URL: http://dspace.pdaa.edu.ua:8080/handle/123456789/4573 (дата звернення: 10.02.2021).

6. Емерсон Г. Двенадцать принципов производительности. Москва : Экономика, 1992. 224 с.

7. Зайцев В.С. Сертифікація персоналу - нова технологія оцінювання компетенцій працівників підприємств. Економічний вісник Донбасу. 2017. № 1(47). С. 119-125.

8. Зось-Кіор М.В., Семенюта М.В. Система оцінки персоналу підприємства в конкурентних умовах ведення бізнесу. Ефективна економіка. 2020. № 2. URL: http://www.economy.nayka.com.ua/?op=1\&z=7648. DOI: 10.32702/2307-2105-2020.2.7 (дата звернення: 28.01.2021).

9. Кибанов А.Я., Дуракова И.Б. Управление персоналом организации: стратегия, маркетинг, интернационализация. Москва : ИНФРА-М, 2005. 301 с.

10. Медунецький В.М., Силаєва К.В. Методологія наукових досліджень. URL: https://docviewer.yandex.ru/ view/121332298/ (дата звернення: 28.01.2021). 


\section{REFERENCES:}

1. Ansoff I. (1989) Strategicheskoe upravlenie [Strategic Management]. Moscow: Ekonomika. (in Russian)

2. Armstrong M. (2002) Strategicheskoe upravlenie chelovecheskimi resursami [Strategic management of a human resources]. Moscow: INFRA-M. (in Russian)

3. Balabanova L.V., Sardak O.V. Upravlinnia personalom [Personnel management]. Available at: http://www.twirpx.com/file/544700/ (accessed 21 January 2021).

4. Byvsheva L.O., Kondratenko O.O., Zheldak S.V., Kovalenchenko A.O. (2020) Stratehichne upravlinnia personalom yak faktor zrostannia konkurentospromozhnosti promyslovoho pidpryiemstva [Strategic personnel management as a factor in increasing the competitiveness of industrial enterprises]. Ekonomichnyi visnyk Donbasu, no. 1 (59), pp. 137-144. Available at: http://dspace.nbuv.gov.ua/bitstream/handle/123456789/170211/20-Byvsheva. pdf?sequence=1 (accessed 15 February 2021).

5. Halych O.A., Vakulenko Yu.V., Tereshchenko I.O., Krutko T.V. (2019) Stratehichne upravlinnia personalom yak faktor zrostannia konkurentospromozhnosti pidpryiemstva [Strategic personnel management as a factor in increasing the competitiveness of the enterprise]. Ahrosvit, no. 6, pp. 27-32. Available at: http://dspace.pdaa.edu.ua: 8080/handle/123456789/4573 (accessed 10 February 2021).

6. Emerson G. (1992) Dvenadtsat printsipov proizvoditelnosti [Twelve performance principles]. Moscow: Ekonomika. (in Russian)

7. Zaitsev V.S. (2017) Sertyfikatsiia personalu - nova tekhnolohiia otsiniuvannia kompetentsii pratsivnykiv pidpryiemstv [Personnel certification is a new technology for assessing the competencies of employees]. Ekonomichnyi visnyk Donbasu, no. 1(47), pp. 119-125.

8. Zos-Kior M.V., Semeniuta M.V. (2020) Systema otsinky personalu pidpryiemstva v konkurentnykh umovakh vedennia biznesu [The system of personnel evaluation of the enterprise in the competitive conditions of doing business]. Efektyvna ekonomika, no. 2. Available at: http://www.economy.nayka.com.ua/?op=1\&z=7648. DOI: 10.32702/2307-2105-2020.2.7 (accessed 28 January 2021).

9. Kibanov A., Durakova I. (2005) Upravlenie personalom organizacii : strategija, marketing, internacionalizacija [Personnel management of organization: strategy, marketing, internationalization]. Moscow: INFRA-M. (in Russian)

10. Medunetskii V.M., Sylaieva K.V. Metodolohiia naukovykh doslidzhen [Research methodology]. Available at: https://docviewer.yandex.ru/view/121332298/ (accessed 28 January 2021). 